\title{
Communication
}

[Comunicação]

\section{Molecular characterization of neuropathogenic Equine Herpesvirus 1 Brazilian isolates}

[Caracterização molecular de isolados brasileiros de herpesvírus equino 1]

\author{
E.A. Costa ${ }^{1}$, R. Rosa ${ }^{1}$, T.S. Oliveira ${ }^{1,2}$, A.C. Assis ${ }^{1}$, T.A. Paixão ${ }^{3}$, R.L. Santos ${ }^{1 *}$ \\ ${ }^{1}$ Escola de Veterinária - Universidade Federal de Minas Gerais - Belo Horizonte, MG \\ ${ }^{2}$ Instituto Mineiro de Agropecuária - Belo Horizonte, MG \\ ${ }^{3}$ Instituto de Ciências Biológicas - Universidade Federal de Minas Gerais - Belo Horizonte, MG
}

Equine herpesvirus 1 (EHV-1) infections cause significant economic losses for horse breeders worldwide due to abortion in pregnant mares, perinatal foal mortality, respiratory illness and neurological diseases in all breeds of horses. Over the past decade, while the prevalence of EHV-1-induced abortions apparently decreased, reports of EHV-1-induced neurological diseases (equine herpesvirus myeloencephalopathy) have been increasing, particularly in Europe and in the United States of America (Pronost et al., 2010). There are several commercially available vaccines that are employed for controlling the respiratory disease and abortion caused by EHV1. However, these vaccines are not reliably protective against EHV-1-induced neurological disease (Goodman et al., 2012).

Molecular characterization of abortion or neurological disorders associated with strains of EHV-1 resulted in identification of differences between them. Although 16 genotypes of EHV-1 have been identified, EHV-1B and EHV-1P are associated with more than $90 \%$ of abortion in mares worldwide, whereas only the genotype EHV-1P has been associated with EHV-1 neuropathogenicity in horses. This genotype emerged from the recombination of the ICP4 gene (ORF64) between EHV-1 and EHV-4 (Pagamjav et al., 2005). Furthermore, studies on EHV-1 pathogenesis relating to induction of abortion or neurological disorders have demonstrated differences in the pathogenic potential that are correlated with the ability to replicate and establish infection in leukocytes and endothelial cells (Nugent et al., 2006).

Recebido em 4 de maio de 2015

Aceito de 13 de julho de 2015

*Autor para correspondência (corresponding author)

E-mail: rsantos@vet.ufmg.br
Infections with neuropathogenic strains are associated with longer and higher level viremia, which interferes with the blood flow to the central nervous systems and the development of neurological diseases (Fritsche and Borchers, 2011). However, the mechanism by which this leukocyte-associated viremia leads to myeloencephalopathy is not yet understood. Further studies indentified a specific mutation $\left(A_{2254}\right.$ to $\left.G_{2254}\right)$ that results in a replacement of an asparagine $(\mathrm{N})$ by an aspartic acid (D) at amino acid position $752\left(\mathrm{~N}_{752}\right.$ to $\left.\mathrm{D}_{752}\right)$ of the EHV-1 DNA polymerase gene (ORF 30). EHV-1 strains carrying this point mutation are considered to have neuropathogenic potential, whereas strains carrying an adenine at position 2254 are considered non neuropathogenic (Nugent et al., 2006). However, the mechanism by which this leukocyte-associated viremia leads to myeloencephalopathy is not yet understood.

Molecular characterization of EHV-1 Brazilian isolates is an important step towards the development of vaccine formulations that include viruses that represent the genotypes circulating in the country. In spite of EHV-1 being considered a conserved virus, vaccine formulations based on strains from other countries may result in suboptimal protection. Furthermore, combination of multiple viral strains in a vaccine formulation may result in a broader protection.

In this study, eight EHV-1 strains isolated from the central nervous system (CNS) of horses that died with neurologic clinical signs in the State of Minas Gerais (Brazil) were molecularly 
characterized. Molecular characterization was based on: (i) classifying the isolates as EHV-1B or EHV-1P genotypes; and (ii) identification of a neuropathogenic marker. Molecular characterization of these isolates may provide the basis for the development of vaccines that may be more efficient for preventing EHV-1-induced neurologic disease.

The EHV-1 strains used in this study $(n=8)$ were obtained in a previous epidemiological survey of encephalitis-causing agents in horses in the State of Minas Gerais (Costa et al., 2015), which also resulted in the first isolation of the Saint Louis Encephalitis virus from a horse with neurological disease (Rosa et al., 2013). Nomenclature of these isolates was established as described by Nugent et al. (2006), according to the country of origin, year of the outbreak, the unique identifier of the outbreak, and pathogenic characteristics of the outbreak ( $\mathrm{p}$ : $0=$ attenuated vaccine strain, $1=$ non neurological isolate, $2=$ neurological isolate). Features of the EHV-1 isolates used in this study are summarized in Table 1.

Table 1. Features of EHV-1 strains isolated from horses with neurologic disease in the State of Minas Gerais, Brazil

\begin{tabular}{llll} 
& Horse & & \\
\cline { 2 - 3 } Strain & gender & age (months) & Location \\
\hline BR09_1_2 & Male & 96 & Várzea da Palma \\
BR09_03_2 & Female & 42 & Abaeté \\
BR09_29_2 & Female & 36 & Entre Rio de Minas \\
BR09_30_2 & Female & 02 & Entre Rio de Minas \\
BR09_66_2 & Female & 24 & Itamarandiba \\
BR09_141_2 & Female & 30 & Pompeu \\
BR09_154_2 & Female & 24 & Ganhães \\
BR10_1232_1 & Female & NA & Viçosa \\
\hline
\end{tabular}

NA=Not available

Prior to molecular analysis, viral strains were grown in Madin Darby bovine kidney (MDBK) cells (ATCC CCL-22) cultured in DMEM (Dulbecco's Modified Eagle Media; Life Technologies, USA) supplemented with $10 \%$ fetal bovine serum (Gibco, USA), 100U/mL of penicillin, and $100 \mu \mathrm{g} / \mathrm{mL}$ of streptomycin (Gibco). Cultures were sequentially subcultured as described below until reaching approximately $70-90 \%$ of characteristic cytopathic effect of EHV-1 (i.e. round cells, detachment of cells, cytoplasmic stranding, vacuolization of the cells, formation of syncytia and lyses plaques) and the isolation was confirmed by PCR after the fourth passage (Varrasso et al., 2001). Viral titers were assessed by determining plaque forming units (PFU) according to Desprès et al. (1993).

Viral DNA was extracted by phenol/chloroform/isoamyl alcohol according to the protocol described by Sambrook et al. (1989). All DNA samples were analyzed for assessing concentration and purity by spectrophotometry. PCRs containing $200 \mathrm{ng}$ of template DNA were performed according to the parameters described in Table 2. PCRs were performed for: (i) differentiation between EHV$1 \mathrm{~B}$ and EHV-1P genotypes and (ii) identification of the neuropatogenic marker.

Table 2. Primers and restriction enzyme utilized to identify the EHV-1P genotype and the neuropathogenic marker

\begin{tabular}{|c|c|c|c|}
\hline Primers & Sequence $\left(5^{\prime}-3^{\prime}\right)$ & Amplicon size & $\begin{array}{l}\text { Restriction } \\
\text { enzyme }\end{array}$ \\
\hline \multicolumn{4}{|l|}{ First Reaction: } \\
\hline ORF30F8 & GTGGACGGTACCCCGGAC & $380 \mathrm{bp}$ & \\
\hline ORF30R2 & GTGGGGATTCGCGCCCTCACC & & \\
\hline \multicolumn{4}{|c|}{ Second Reaction: } \\
\hline ORF30F7 & GGGAGCAAAGGTTCTAGACC & $256 \mathrm{bp}$ & SalI* \\
\hline
\end{tabular}


The primers: Pr1 5, (sense ACGCCCCCTTCGTTCCTC - 3') and Pr2 5' (antisense - CGCTCCACCTCGGTCCTG -3') were used for differentiating between EHV-1B and EHV-1P genotypes (Mori et al., 2012). These primers amplify only the ICP-4 gene of type $\mathrm{P}$, which has not undergone recombination with the natural EHV-4. The conditions of the PCR were performed as described by Mori et al. (2012). DNA samples from all eight EHV-1 isolates yielded a 436 base pairs (bp) PCR product, indicating that they all belong to the $\mathrm{P}$ genotype (EHV-P).
Identification of the neuropathogenic marker was based on amplification of EHV-1 ORF30 by nested PCR followed digestion with the restriction enzyme SalI (Life Technologies) according to Allen et al. (2006). The primer sequences and description of the digested products are detailed in Table 2. The substitution of an adenine by a guanine at the position 2,254 $\left(\mathrm{A}_{2254}-\mathrm{G}_{2254}\right)$ introduces a SalI restriction site. DNA samples from all eight EHV-1 isolates yielded a product of $256 \mathrm{bp}$ in nested-PCR, which was digested by SalI, indicating that they all carry this neuropathogenic marker (Figure 1).

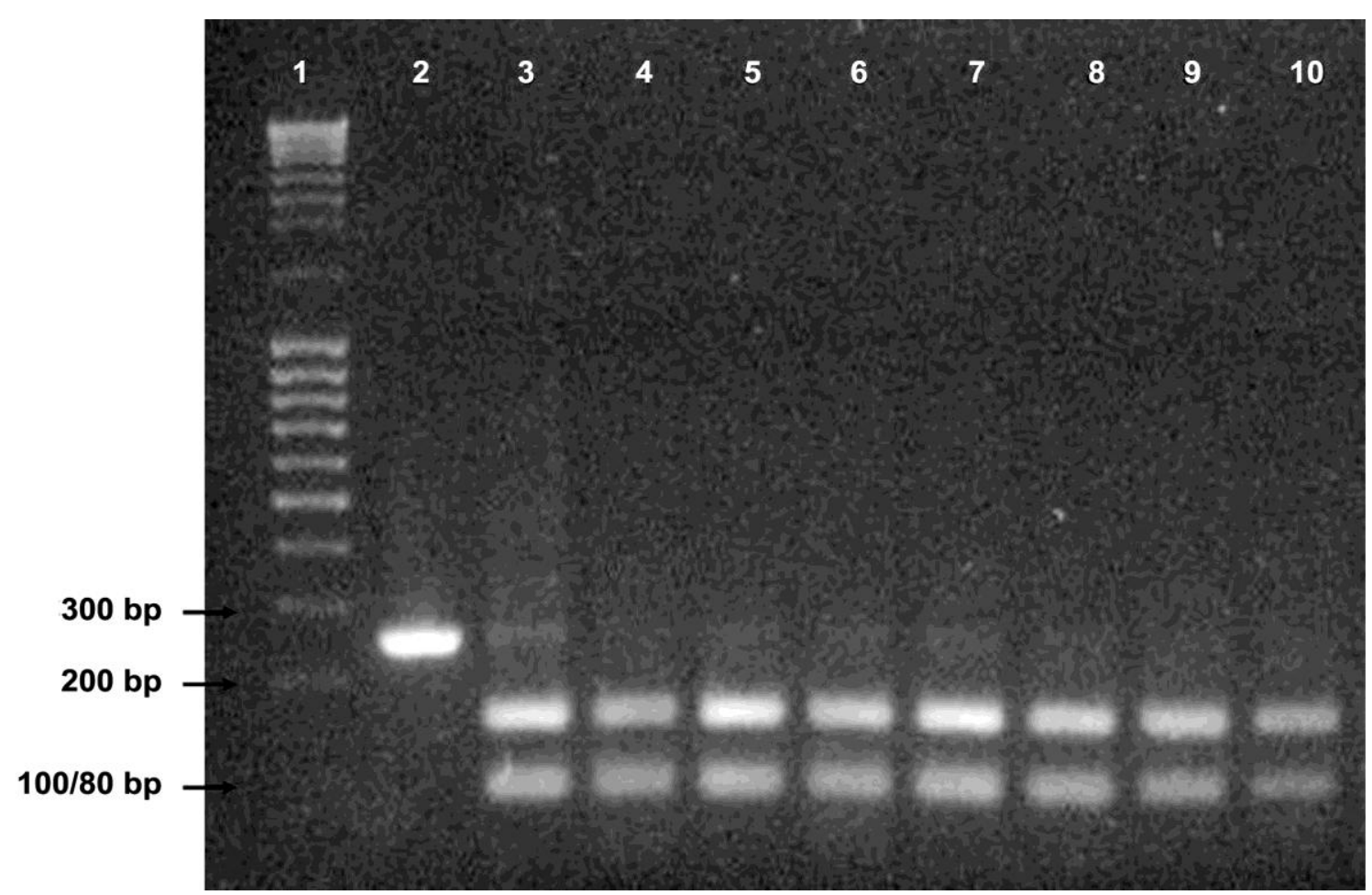

Figure 1. Restriction enzyme SalI digest after nested-PCR amplification. Lane 1: Molecular Marker MassRuler DNA Ladder; lane 2: Isolated BR09_1_2 undigested; lane 3: Isolated BR09_1_2 digested; lane 4: Isolated BR09_29_2 digested; lane 5: Isolated BR09_30_2 digested; lane 6: Isolated BR10_1232_1 digested; lane 7: Isolated BR09_03_2 digested; lane 8: Isolated BR09_66_2 digested; lane 9: Isolated BR09_141_2 digested; lane 10: Isolated BR09_154_2 digested.

To confirm the neuropathogenic marker, PCR products of six isolates of EHV-1 (BR09_1_2, BR09_29_2, BR09_30_2, BR09_66_2, BR09_141_2 and BR10_1232_1) were sequenced by the Sanger method using the automated sequencing system Megabace 1000 (Amersham Bioscience, UK) and the commercial
Kit DyEnamic ET Dye Terminator (Amersham Bioscience) according to the manufacturer's instructions. The consensus and quality of these sequences were assessed using the website program http://asparagin.cenargen.embrapa.br/ $\mathrm{phph} /$. Consensus sequences were then compared (http://multalin.toulouse.inra.fr/multalin/) with 
two sequences of EHV-1 in Genbank (http://www.ncbi.nlm.nih.gov/): AB4 strain (Genbank number DQ180669), reference neuropathogenic strain and V592 (Genbank number DQ172359) reference non neuropathogenic strain. Indeed, isolates that were sequenced had the $\mathrm{G}_{2254} / \mathrm{N}_{752}$ point mutation, further supporting their classification as carriers of the neuropathogenic marker (Figure 2).

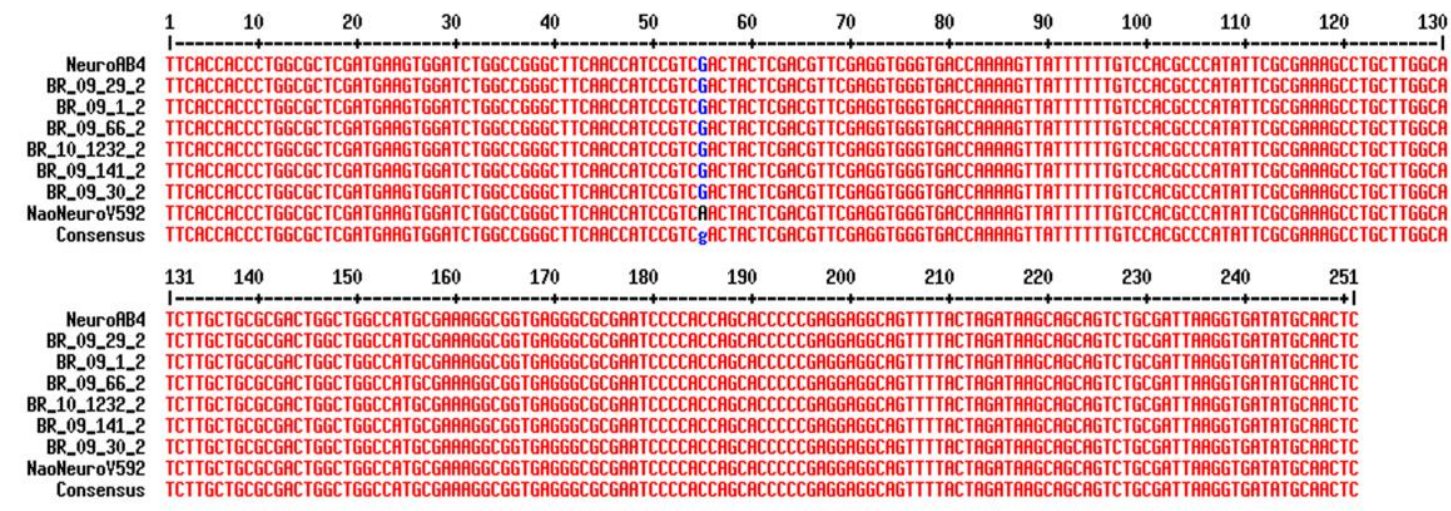

Figure 2. Alignment of partial sequences of EHV-1 ORF30 gene from the field isolates BR09_1_2, BR09_29_2, BR09_30_2, BR09_66_2, BR09_141_2, and BR10_1232_1 with AB4 strain (Genbank number DQ180669), reference neuropathogenic strain and V592 (Genbank number DQ172359) reference non neuropathogenic strain.

The results presented here show that all the EHV-1 strains isolated from central nervous system of horses that died with neurological signs match neuropathogenic variant $\left(\mathrm{G}_{2254} / \mathrm{D}_{752}\right)$. The virus with neuropathogenic genotype has been recognized since the 1950's, and the incidence of these isolates increased exponentially every year, leading to an increasing risk for outbreaks of equine herpesvirus neurologic disease (Smith et al., 2010).

Furthermore, EHV-1 which possesses this neuropathogenic genotype has been associated with sporadic cases of EHV-1 abortion and was increased in comparison to previous decades in the USA and Europe. This is a concern to researchers and horse breeders worldwide since the vaccine against EHV-1 abortion does not protect against neurological diseases and the association of neurophatogenic strains with abortions can lead to inefficiency of the commercial vaccines. In spite of research efforts worldwide EHV-1 neuropathogenesis is still poorly known.

Keywords: horse, neuropathogenic equine herpesvirus -1 , encephalitis

\section{RESUMO}

Este trabalho descreve a caracterização molecular de oito amostras de herpesvírus equino 1 isoladas do sistema nervoso central de equinos que morreram com sinais neurológicos no estado de Minas Gerais. As amostras de EHV-1 foram isoladas em cultivo celular, e a caracterização molecular foi feita por genotipagem e identificação do marcador neuropatogênico por meio das técnicas de PCR, restrição enzimática e sequenciamento. A caracterização molecular desses isolados pode ser a base para o desenvolvimento de novas formulações vacinais com maior eficácia para a prevenção de doença neurológica causada pelo EHV-1.

Palavras-chave: equino, herpesvírus equino 1 neuropatogênico, encefalite 


\section{ACKNOWLEDGEMENTS}

Work at RLS lab is supported by $\mathrm{CNPq}$ (Conselho Nacional de Desenvolvimento Científico e Tecnológico, Brazil) and FAPEMIG (Fundação de Amparo a Pesquisa do Estado de Minas Gerais, Brazil). This study was supported by Laboratórios Vencofarma do Brasil.

\section{REFERENCES}

ALLEN, G.P. Antemortem detection of latent infection with neuropathogenic strains of equine herpesvirus-1 in horses. Am. J. Vet. Res., v.67, p.1401-1405, 2006.

COSTA, E.A.; ROSA, R.; OLIVEIRA, T.S. et al. Diagnóstico etiológico de enfermidades do sistema nervoso central de equinos no estado de Minas Gerais, Brasil. Arq. Bras. Med. Vet. Zootec., 2015. No prelo.

DESPRÈS, P.; FRENKIEL, M.P.; DEUBEL, V. Differences between cell membrane fusion activities of two dengue type- 1 isolates reflect modifications of viral structure. Virology, v.196, p.209-219, 1993.

FRITSCHE, A.K.; BORCHERS, K. Detection of neuropathogenic strains of equid herpesvirus 1 (EHV-1) associated with abortions in Germany. Vet. Microbiol., v.147, p.176-180, 2011.

GOODMAN, L.B.; WIMER, C.; DUBOVI, E.J. et al. Immunological correlates of vaccination and infection for equine herpesvirus 1. Clin. Vaccine Immunol., v.19, p.235-241, 2012.

MORI, C.M.C.; MORI, E.; FAVARO, L.L. et al. Equid herpesvirus type-1 exhibits neurotropism and neurovirulence in a mouse model. J. Comp. Pathol., v.146, p.202-210, 2012.
NUGENT, J.; BIRCH-MACHIN, I.; SMITH, K.C. et al. Analysis of equid herpesvirus 1 strain variation reveals a point mutation of the DNA polymerase strongly associated with neuropathogenic versus nonneuropathogenic disease outbreaks. J. Virol., v.80, p.4047-4060, 2006.

PAGAMJAV, O.; SAKATA, T.; MATSUMURA, T. et al. Natural recombinant between equine herpesviruses 1 and 4 in the ICP4 gene. Microbiol. Immunol., v.49, p.167179, 2005.

PRONOST, S.; COOK, R.F.; FORTIER, G. et al. Relationship between equine herpesvirus-1 myeloencephalopathy and viral genotype. Equine Vet. J., v.42, p.672-674, 2010.

ROSA, R.; COSTA, E. A.; MARQUES, R. E. et al. Isolation of Saint Louis Encephalitis Virus from a horse with neurological disease in Brazil. PLoS Negl. Trop. Dis., v., p.e2537, 2013.

SAMBROOK, J.; FRITSCH. E.F.; MANIATS, T. Molecular cloning: a laboratory manual. New York: Cold Spring Harbor, 1989. 545p.

SMITH, K.L.; ALLEN, G.P.; BRANSCUM, A.J. et al. The increased prevalence of neuropathogenic strains of EHV-1 in equine abortions. Vet. Microbiol., v.141, p.5-11, 2010.

VARRASSO, A.; DYNON, K.; FICORILLI, N. et al. Identification of equine herpesviruses 1 and 4 by polymerase chain reaction. Aust. Vet. J., v.79, p.563-569, 2001. 